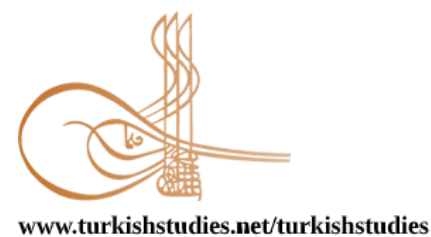

Turkish Studies

\title{
Covid-19 Pandemisinin Giyim Kuşama Tematik Yansımaları: Maske Kullanımı
}

\author{
Thematic Reflections of The Covid-19 Pandemic to Clothing: Using the Mask
}

\author{
Nazan Avcıŏglu Kalebek* - Gökçe Özdemir**
}

\begin{abstract}
COVID-19, which emerged in Wuhan city of Hubei province of China, now affects the whole world since December 2019. The epidemic has been proven to be transmitted from person to person through droplet, contact and breathing. The virus continues to spread rapidly despite the global prevention and quarantine efforts since the World Health Organization (WHO) has been accepted as a pandemic. It cancels the progression of the disease for public life. One of these measures is the necessity to use a face mask. This is a questionnaire study on the use of masks. This study is a research in descriptive screening model in which a questionnaire study on mask use is performed. Research datas prepared by investigators with the questionnaire consists of 20 questions Gaziantep province different age and education level with the variables were collected from female participants. The ethical permission required to conduct the research was obtained from Gaziantep University. Based on the research findings, it was concluded that the younger age group did not care much about the disease, the rate of wearing a mask increased as the level of education increased, and the people living in the countryside preferred to use a mask less. When the mask preferences were examined, it was determined that the female participants participating in the survey preferred the surgical mask that should be worn for protection from the epidemic, instead of the fancy mask in their choice of mask. As a result, it was concluded that the participants did not consider the use of masks as a visual pollutions, they preferred to use masks because they care about protecting themselves and other family members, and that the opinions about the use of masks differ according to the variables of education level, age and place of residence.
\end{abstract}

Structured Abstract: Epidemics are recognized as disasters that pose a serious threat to societies nowadays. Plague, cholera, tuberculosis, syphilis, malaria, typhus, flower, measles, diphtheria, Spanish fever, SARS, Ebola, Zika, and finally COVID-19 are the examples of these epidemics. More than 120 countries in the world include Turkey, pandemic Covid-19 still threat to humans. It is also known that the disease is transmitted by droplets such as cough, sneezing and airway to the mucous membrane of the hand, mouth, ear and eye as a result of contact with sick people. For this reason, the use of social isolation and personal protective equipment (mask, gloves, semen, etc.) in the prevention of contamination is seen as a shield for the transmission of the disease. Among these measures, the use of masks is at the top.

\footnotetext{
* Doç.Dr., Gaziantep Üniversitesi, Güzel Sanatlar Fakültesi, Moda ve Tekstil Tasarımı Assoc. Prof. Dr., Gaziantep University, Fine Art Faculty, Fashion and Textile Design ORCID 0000-0002-1840-034X nkalebek@gantep.edu.tr

** Dr. Öğr. Üyesi, Gaziantep Universitesi, Güzel Sanatlar Fakültesi, Moda ve Tekstil Tasarımı Assist.Prof.Dr., Gaziantep University, Fine Art Faculty, Fashion and Textile Design ORCID 0000-0002-2608-6004 gozdemir@gantep.edu.tr

Cite as/ Atıf: Avcıoğlu Kalebek, N., Özdemir, G. (2020). Covid-19 pandemisinin giyim kuşama tematik yansımaları: Maske kullanımı. Turkish Studies, 15(4), 57-68. https://dx.doi.org/10.7827/TurkishStudies.43966 Received/Geliş: 03 June/Haziran 2020 Checked by plagiarism software Accepted/Kabul: 10 August/Ağustos 2020 Published/Yayın: 30 August/Ağustos 2020 Copyright (C) MDE, Turkey 
A questionnaire study on the use of masks against Covid-19 disease, which is the subject of our study, was conducted. The research datas were collected through a 20-item questionnaire, "The Use of Mask in the Covid 19 Pandemic Outbreak" created by the researchers (Table 1).

Table 1: Participants' Opinions on theUse of the Mask

\begin{tabular}{|c|c|c|c|}
\hline Title & Expressions & $\overline{\mathrm{X}}$ & Ss \\
\hline 1 & $\begin{array}{l}\text { I think the necessity of wearing a mask in this period } \\
\text { affects me economically. }\end{array}$ & 2,01 & 0,19 \\
\hline 2 & I think the mask as part of my dress. & 2,84 & 1,54 \\
\hline 3 & I feel like wearing a mask when going out is a must. & 4,26 & 1,26 \\
\hline 4 & I think wearing masks are as visual pollution. & 1,93 & 1,32 \\
\hline 5 & $\begin{array}{l}\text { I think the mask protects me from infection by the } \\
\text { new type of Corona- } 19 \text { Covid virus. }\end{array}$ & 3,73 & 1,25 \\
\hline 6 & $\begin{array}{l}\text { I think that when I wear a mask, I give a social } \\
\text { message. }\end{array}$ & 4,15 & 1,20 \\
\hline 7 & $\begin{array}{l}\text { When purchasing a mask, I consider the mask } \\
\text { protect me. }\end{array}$ & 4,20 & 1,16 \\
\hline 8 & I prefer to wear masks with a visual image. & 2,32 & 1,45 \\
\hline 9 & I sew my own mask at home. & 1,86 & 1,21 \\
\hline 10 & $\begin{array}{l}\text { I decorate the masks that I sew or buy from outside } \\
\text { to look beautiful. }\end{array}$ & $1,69^{*}$ & 1,15 \\
\hline 11 & I do not find the current sold masks aesthetic. & 2,53 & 0,36 \\
\hline 12 & $\begin{array}{l}\text { I use different masks according to the place and } \\
\text { place. }\end{array}$ & 1,77 & 1,26 \\
\hline 13 & $\begin{array}{l}\text { I prefer to use fabric masks rather than surgical } \\
\text { masks. }\end{array}$ & 2,21 & 0,46 \\
\hline 14 & I prefer to use washable masks. & 2,48 & 1,56 \\
\hline 15 & $\begin{array}{l}\text { I take care that the masks I bought or sewed are easy } \\
\text { to put on and take off. }\end{array}$ & 3,79 & 1,46 \\
\hline 16 & $\begin{array}{l}\text { When going out I care about not only myself but } \\
\text { also all family members. }\end{array}$ & $4,53^{*}$ & 1,06 \\
\hline 17 & $\begin{array}{l}\text { When I buy a mask, I prefer a patterned, colorful, } \\
\text { suitable fabric for my clothes. }\end{array}$ & 1,91 & 1,37 \\
\hline 18 & $\begin{array}{l}\text { When buying a mask, I pay attention to the fact that } \\
\text { it is a classic white surgical mask. }\end{array}$ & 3,44 & 1,51 \\
\hline 19 & $\begin{array}{l}\text { I definitely prefer wearing a mask in places that are } \\
\text { not mandatory. }\end{array}$ & 3,80 & 1,38 \\
\hline 20 & $\begin{array}{l}\text { I dispose of the medical mask after using it several } \\
\text { times, not for single use. }\end{array}$ & 2,51 & 1,46 \\
\hline AVERAGE & & 2,90 & ,506 \\
\hline
\end{tabular}

While creating the questionnaire, a related field scan was made for the use of masks and then submitted to the examination of 2 field experts. After controlling the field experts, the necessary corrections were made by reading the items to 10 people who were not included in the sample in order to test the understandability of the survey items. A 5-point Likert-type (1: Never, 5: Always) rating was used to evaluate the questionnaire items. After the data were collected, KMO and Bartlett's Test were done for the adequacy of the sample size. 376 female participants between the ages of 20-60 were included in this study. the group of the study. $66.8 \%$ (251 people) of the participants reside in the city center, $23.7 \%$ ( 89 people) in the district, $9.6 \%$ (36 people) in the countryside. In terms of education level, the participants are $3.9 \%$ (15 people) primary school, $5.9 \%$ (22 people) secondary school, $17.3 \%$ high school (65 people) and $72.8 \%$ (274 people) higher education level is in the group. In addition, while $44.1 \%$ (166 people) of the study participants are employed people, $55.9 \%$ (210 people) do not work in any job. When the distribution of the participants according to age ranges is examined, $52.1 \%$ (196 people) $20-30$ years old $23.7 \%$ (89 people), 31-40 years 
old, $19.7 \%$ (74 people) $41-50$ years old nand $4.5 \%$ (17 people) are between the ages of 51-60. Research data were analyzed with SPSS 25.0 package program.

According to the arithmetic averages of the answers given by the participants to each item related to the use of masks, "I care that not only myself but all family members wear them when going out" and item $16(\overline{\mathrm{X}}=4.53)$ and the lowest mean "Masks that I sew or purchased from abroad I adorn it so that it looks beautiful. " Article $10(\overline{\mathrm{X}}=1.69)$. In addition, the general average of the questionnaire items $(\overline{\mathrm{X}}=2.96)$ is at the level of "Occasional".

As a result, with the Covid-19 epidemic that is emerging today, it is possible to overcome the epidemic to a minimum by using technological opportunities. Thanks to advanced smart technology, information about the epidemic was obtained in a short time and it was found that it is possible to reduce the spread of the disease by simple methods such as wearing a mask, hand washing and social isolation. As a result, it has become inevitable how important personal protective measures are in these and similar outbreaks and that these protective measures should now become a part of our lives. Without underestimating the risk factors associated with the outbreak of individuals, applying the necessary measures in the light of scientific data will be transformed into positive gains for both individual and public health.

Keywords: Pandemic, Covid-19, DisposableFace Mask, Clothing-Apparel

Öz: Çin'in Hubei eyaleti Wuhan şehrinde ortaya çıkıp şu an tüm dünyayı etkisi altına alan COVID-19 pandemisi Aralık 2019'dan bu yana halen etkisini sürdürmektedir. Salgının damlacık, temas ve solunu yolu ile insandan insana bulaştığı kanıtlanmıştır. Dünya Sağlık Örgütü’nün (WHO) durumu pandemi olarak ilan etmesine, küresel önlem ve karantina çabalarına rağmen virüs hızla yayılmaya devam etmektedir. Toplu yaşam alanlarında hastalığın ilerlemesini engellemek amacıyla birçok önlem alınmaktadır. Bu önlemlerden birisi de yüz maskesi kullanma zorunluluğudur. Bu çalışma, maske kullanımı ile ilgili anket çalışmasının yapıldığı betimsel tarama modelinde bir araştırmadır. Araştırma verileri, araştırmacılar tarafından hazırlanmış 20 sorudan oluşan anket ile Gaziantep ilinde ikamat eden farklı, yaş ve eğitim seviyesi değişkenlerine sahip kadın katılımcılardan toplanmıştır. Araştırmanın yapılabilmesi için gerekli etik izin Gaziantep Üniversitesinden alınmıştır. Araştırma bulgularına bağlı olarak, küçük yaş grubunun hastalığı pek önemsemediği, eğitim düzeyi yükseldikçe maske takma oranının arttığı ve kırsal kesimde yaşayan insanların maske kullanmayı daha az tercih ettiği sonucuna ulaşılmıştır. Maske tercihleri incelendiğinde, ankete katılan kadın katılımcıların maske tercihinde süslü maske yerine, salgından koruma amaçlı takılması gereken cerrahi maskeyi öncelikledikleri saptanmıştır. Özetle, katılımcıların maske kullanımını bir görsel kirlilik olarak görmedikleri, kendileri ve diğer aile bireylerini korumayı önemsedikleri için maske kullanmayı tercih eğilimlerinin yüksek olduğu, eğitim düzeyi, yaş ve ikamet edilen yer değişkenlerine göre maske kullamına yönelik görüşlerin farklılaştığı sonucuna ulaşılmıştır.

Anahtar Kelimeler: Pandemi, Covid-19, Tek Kullanımlık Yüz Maskesi, Giyim-Kuşam

\section{Giriş}

Salgın hastalıklar, bilinen tarihler sürecinde toplumlar için ciddi tehdit oluşturan afetler olarak kabul edilmektedirler. Bu salgın hastalıklara; veba, kolera, verem, frengi, sıtma, tifüs, çiçek, kızamık, difteri, İspanyol nezlesi, SARS, Ebola, Zika ve son olarak da COVID-19 örnek gösterilebilir (Gönüllü, 2008; Şimşek, 2020; Doğan, 2017; Kaya \& Kıy1l1, 2014; Yücel, 2019). Bu salgın hastalıklar, insan yaşamını tehdit ederek ölümlere sebep oldukları için birçok devlet bu dönemlerde salgına karşı önemli mücadeleler vermişlerdir. Günümüzde de Covid-19 için tüm dünya ülkeleri mücadele kapsamında önemli tedbirler almışlar ve almaya da devam etmektedirler. Bunların başında karantina ve koruyucu tedbirler gelmektedir. Covid-19; öksürük, hapşırma gibi belirtileri olan, hasta kişiler ile temas etme sonucunda el, ağız, kulak ve gözün mukozaya götürülmesi ile de bulaştı̆̆ı bilinen bir hastalıktır (Balachandar vd., 2020). Bu nedenle, bulaşıcılığın önlenmesinde sosyal izolasyon ve kişisel koruyucu ekipman kullanımı (maske, eldiven, sperlik vb.) hastalığın bulaşmasına bir kalkan olarak görülmektedir. Özellikler nüfus yoğunluğun fazla olduğu şehirlerde yakın temasın ve yüksek hareketliliğin olduğu toplu taşıma araçlarında ve ortak kullanım 
yerlerinde sıkı önleyici tedbirler uygulanmaktadır. Bu tedbirler arasında çalışmamıza konu alan maske kullanımı zorunluluğuda yer almaktadır (Akgül, 2020; Kına vd., 2020; Özdemir Deniz \& Evci Kiraz, 2020; Özkan vd., 2020; Balachandar vd., 2020).

Aslan (2020) ve Acar (2020) yaptıkları çalışmalarında dünya üzerinde çok geniş coğrafyalara etki eden, insanlar ve hayvanlarda ciddi rahatsızlıklara, hatta ölümlere sebep olan salgınları incelemişlerdir. Yapılan çalışmalarda, diğer endemik durum mücadelelerin de olduğu gibi Covid-19 ile mücadeledeki öncelikler; temas ve kontaminasyondan uzak durmak, ağız, göz, burun, kulak gibi vücudun bulaşımına açık bölgelerini korumak ve etkin dezenfekte işlemlerini uygulamak olarak sıralanmıştır. Covid-19 salgını karşısında tün dünya devletleri salgın döneminde otoriterilerini en üst düzeyde kullanmışlar, Covid-19'a karşı verilen mücadeleyi biyolojik savaş olarak yani görünmez düşman ile mücadele olarak tanımlamışlar ve bu süreçte, devletler ciddi ekonomik krizlerle başetmek zorunda kalmışlardır (Acar, 2020). Alpago ve Oduncu Alpago (2020), virüs kaynaklı Covid-19 salgınının sosyo-ekonomik etkilerini değerlendirerek, başta sağlık ve eğitim olmak üzere birçok sektörde dijitalleşme ve on-line işlemlerin ağırlık kazandığını belirtmişlerdir. Bu da beraraberinde Covid-19 salgını ile ilgili birçok bilimsel çalışmaların ağırlık kazanmasını ve köklü değişimlere yol açacak çözüm odaklı projelerin geliştirilmesini getirmiştir. Bilindiği gibi COVID-19, hasta olan kişilerin öksürme veya hapşırma yolu ile yüzeylere saçtığ damlacıklara temas sonrası etkenin mukozalara temas etmesi ile bulaşmaktadır. Uzmanlar bu bulaşı en aza indirgemenin en temel kuralları içerisinde ev dışı alanlarda maske kullanımı olduğunu ifade etmektedirler. Soysal, İşler, Peker, Akca, Özmeriç ve Ünsal (2020), Covid- 19 enfeksiyonunun yayılma olasılığına karşı alınması gereken temel koruma önlemlerinin; tek kullanımlık bone, tek kullanımlık cerrahi maske, beyaz önlük, koruyucu gözlük veya yüz koruyucu, tek kullanımlık lateks veya nitril eldivenlerin kullanılması gibi standard önlemlerden oluştuğunu ifade etmişlerdir. Yalçın (2020) ise Covid-19 ve benzeri hastalıklardan korunmak amacıyla kullanılan maske çeşitleri ve kişişel koruyucu ekipmanlar hakkındaki yaptığı çalışmasında en sıklıkla kullanılan maskelerin; ev tipi, cerrahi, solunum ve yarı yüz\&tam yüz maskelerin olduğunu ifade etmiştir. Alanda yapılan çalışmalar göstermektedir ki, bu enfeksiyonunun yayılma hızının azaltılmasında kurallarına uygun yardımcı ekipman kullanımı oldukça önemlidir. Covid-19 ve buna benzer salgın hastalıklar sadece kişilerin değil, sağlık çalışanlarında çalışma şartlarında ciddi değişikliklere gidilmesini kaçınılmaz bir hale getirmiştir. Amerika Birleşik Devletleri Centers for Disease Control and Prevention (CDC), Diş Hekimliği için Kişisel koruyucu ekipmanlar giyilirken ve çıkartılırken kurallara uygun bir şekilde bone, önlük, maske, gözlük, yüz koruyucu ve eldiven sırasıyla giyilmesine ve bu ekipmanların çıkarımı sırasında da eldiven, yüz koruyucu, gözlük, önlük, bone, maske sırasına dikkat edilmesi gerektiğine dikkat çekmiştir (Lu, Stratton \&Tang, 2020). Covid-19 salğınının önlenmesine yönelik farklı kaynaklarda farklı öneriler olmasına karşın, tüm önerilerde genel olarak, sosyal izolasyon, maske ve dezenfektan kullanımının toplumda işlerlik kazanmasının ön plan çıktığı görülmektedir. Türkiye Cumhuriyeti Devleti de bu bağlamda salğının hızla yayılmaya başladığı ilk aylarda vatandaşlarına ücretsiz maske dağıtımı yaparak, kişilerin maske kullanımını bir yaşam biçimi haline getirmelerini desteklemeye çalışmıştır. Özellikle maske kullanımın toplumda işlerlik kazanabilmesi için, 20-65 yaş aralığında yer alan kişiler için maske kullanımının önemine yönelik kamu spotları yapılmıştır (Üstün \& Özçiftçi, 2020). Zaman içerisinde birçok ülkenin vatandaşı için maske kullanımını zorunluluk haline getirmesi beraberinde koruyucu ekipman (maske, siperlik, dezenfaktan vb.) fiyatlarının olması gerektiğinden daha yüksek fiyatlara satılmasına sebep olmuştur (Özkoçak, Koç \& Gültekin, 2020). Bu bağlamda, gündelik yaşam içerisinde kullanımı zorunluluk haline gelen maskelerin bulunamaması ve aile bütçesine oluşturduğu ekstra maliyetin kişileri kendi maskelerini dikme eğilimine de götürdüğünü söyleyebiliriz.

$\mathrm{Bu}$ çalışma ile Covid-19 pandemisinin giyim kuşama tematik yansımalarını, maske kullanımına yönelik görüşler doğrultusunda ortaya çıkarmak amaçlanmaktadır. Bu amaç 
doğrultusunda Covid-19 hastalığına karşı maske kullanımını ile ilgili anket çalışması yapılmış ve farklı demografik değişkenlere göre anket sonuçları yorumlanmıştır.

\section{Yöntem}

Araştırma, bir konuya ya da olaya ilişkin katılımeı görüşlerinin, ilgilerinin, beceri, tutum benzeri özelliklerinin (Fraenkel\&Wallen, 2006) belirlendiği tarama modelinde, betimsel bir çalışma olarak tasarlanmıştır. Bu bağlamda araştırmada, farklı demografik değişkenlere ait kişilerin maske kullanıma yönelik görüşlerinin ortaya çıkarılması amaçlanmaktadır. Araştırma süresince tüm etik kurallara uyulmuş ve araştırmanın uygunluğu için Gaziantep Üniversitesi Etik Kurul Komisyonu 20.05.2020 tarih 6 'nolu toplantı tutanağı ile gerekli izini vermiştir.

\section{Çalışma grubu}

Araştırmanın çalışma grubuna, Gaziantep ilinde ikamet eden 20-60 yaş aralığındaki kadınlar katılımcılar dâhil edilmiştir. Araştırmanın örneklemi ise, çalışma grubundaki herkesin örnekleme dâhil olmada eşit ve bağımsız olma şansına sahip olma olasılığının sağlanması amacıyla basit rastlanstısal (tesadüfi) örnekleme yöntemine göre seçilmiş, 376 kadın katılımcıdan oluşmaktadır. Örneklem grubuna dâhil olan katılımcılar gönüllülük esaslı olarak ankete katılmışlardır. Katılımcıların, \%66,8'i (251 kişi) il merkezi, \%23,7'si (89 kişi) ilçe, \%9,6'sı (36 kişi) kırsal bölgede ikamet etmektedir. Katılımcılar eğitim düzeyi bakımından, \%3,9'u (15 kişi) ilkokul, \%5,9'u (22 kişi) ortaokul, \%17,3'ü lise (65 kişi) ve \%72,8’i (274 kişi) yükseköğretim düzeyi grupta yer almaktadırlar. Ayrıca araştırmaya katılanların \%44,1'i (166 kişi) çalışan kişiler iken, \%55,9'u (210 kişi) herhangi bir işte çalışmamaktadır. Katılımcıların yaş aralıklarına göre dağglımları incelendiğinde \%52,1'i (196 kişi) 20-30 yaş \%23,7'si (89 kişi), 31-40 yaş, \%19,7'si (74 kişi) 41-50 yaş ve \%4,5'i (17 kişi) 51-60 yaş aralığında yer almaktadırlar.

\section{Veri toplama aract}

Araştırma verileri, araştırmacılar tarafindan oluşturulan 20 maddelik "Covid 19 Pandemik Salgınında Maske Kullanımı” adlı anket ile toplanmıştır. Anket oluşturulurken, maske ve maske kullanımına yönelik ilgili alan taraması yapılmış ve sonrasında 2 alan uzmanının incelenmesine sunulmuştur. Alan uzmanlarını incelemesinin ardından anket maddelerinin anlaşılabilirliğini test etmek amaçlı örnekleme dâhil edilmeyen 10 kişiye maddeler okutularak, gerekli görülen düzeltmeler yapılmışırı. Anket maddelerinin değerlendirilmesinde 5'li likert tipi (1:Hiçbir zaman, 5:Her zaman) derecelendirme kullanılmıştır. Veriler toplandıktan sonra örneklem büyüklügünün yeterliği için KMO ve Bartlett's Testi yapılmıştır. Analiz sonucunda KMO değeri .74, Barlett Sphericity testi değeri ise $\mathrm{X}^{2=} 1376.394(\mathrm{p}=.000 ; \mathrm{p}<.001 ; \mathrm{df}=190)$ olarak bulunmuştur. Field (2009) 0.5 ile 0.7 arasındaki KMO değerlerinin orta, 0.7 ile 0.8 arasındaki değerlerin iyi, 0.8 ile 0.9 arasındaki değerlerin çok iyi ve 0.9 'un üzerindeki değerlerin ise mükemmel olduğunun kabul edildiğini ifade etmektedir. Ölçüm sonucu. $74>.50$ olduğu için veri setinin faktör analizi için uygun olduğu söylenebilir. Anketin güvenirliğini test etmek amaçlı Cronbach's Alpha iç tutarlık katsayısı hesaplanmış $\alpha=.75$ bulunmuştur. Güvenirlik katsayısının. 70 ve üstü değerde olması durumunda ölçme aracının yüksek derecede güvenilir olduğu kabul edilir (Büyüköztürk vd., 2014).

\section{Veri analizi}

Araştırma verileri SPSS 25.0 paket programı ile analiz edilmiştir. Demografik değişkenler sınıflama özelliği taşımasından dolayı bu özelliklerin analizinde betimsel istatistikler kullanılmıştır. Ayrıca analizlerde kullanılacak testlere karar verebilmek amaçlı verilerin normal dağılım gösterip göstermedikleri hesaplanmıştır. Analiz sonucunda: çarpıklık (skewness) değeri, .126, basıklık (kurtosis) değeri: .016 olarak bulunmuştur. Çarpıklık (skewness) ve basıklık (kurtosis) değerleri değerlendirildiğinde, değerler \pm 1 değerleri içinde yer aldığından dolayı verilerin normal dağılım gösterdikleri söylenebilir (Büyüköztürk vd., 2014; Morga, Leech, Gloeckner ve Barret, 2004). Veriler normal dağılım gösterdiklerinden dolayı analizlerde parametrik testler kullanılmıştır. 
Katılımcıların çalışıp, çalışmama durumu değişkeninin anlamlı farklılığını belirlemek için t-testi uygulanırken, ikamet edilen bölge, eğitim düzeyi ve yaş değişkenlerinin anlamlı farklılıklarını belirlemek için tek yönlü varyans analizi Anova testi uygulanmıştır.

\section{Bulgular}

Covid-19 pandemisi ölümle sonuçlanan olguların yanında, hastalığa yakalanan ancak zamanla iyileşenlerin de olduğu bir süreç olarak tanımlanmaktadır. Bu süreçte hastalığa yakalanma olasılığını ya da hastalığı başkalarına bulaştırma olasılığını azaltabilmek için gerek devlet yetkilileri, gerekse sağlı çalışanları toplumun her kesiminin ve her yaş grubunda yer alan bireylerin maske kullanmalarını önermektedir. Araştırmaya katılan katılımcıların maske kullanımına yönelik görüşleri Tablo 1'de yer almaktadır.

Tablo 1: Katılımcıların Maske Kullanımına Yönelik Görüşleri

\begin{tabular}{|c|c|c|c|}
\hline $\begin{array}{c}\text { Mad. } \\
\text { no }\end{array}$ & İfadeler & $\overline{\mathrm{X}}$ & Ss \\
\hline 1 & $\begin{array}{l}\text { Bu dönemdeki maske takma zorunluluğunun ekonomik olarak } \\
\text { beni etkilediğini düşünüyorum. }\end{array}$ & 2,01 & 0,19 \\
\hline 2 & Maskeyi, giyim-kuşamımın bir parçası olarak görüyorum. & 2,84 & 1,54 \\
\hline 3 & $\begin{array}{l}\text { Dişarıya çıarken maske takmayı bir zorunluluk olarak } \\
\text { hissediyorum. }\end{array}$ & 4,26 & 1,26 \\
\hline 4 & Maske takmayı görsel kirlilik olarak görüyorum. & 1,93 & 1,32 \\
\hline 5 & $\begin{array}{l}\text { Maskenin beni yeni tip Corona-19 } \\
\text { bulaşmasından koruduğunu düşünüyorum. }\end{array}$ & 3,73 & 1,25 \\
\hline 6 & $\begin{array}{l}\text { Giyim-kuşamda olduğu gibi, maske taktığım zamanda bir } \\
\text { toplumsal mesaj verdiğimi düşünüyorum. }\end{array}$ & 4,15 & 1,20 \\
\hline 7 & $\begin{array}{l}\text { Maske satın alırken maskenin koruma faktörünü göz önünde } \\
\text { bulunduruyorum. }\end{array}$ & 4,20 & 1,16 \\
\hline 8 & Görsel görüntüsü güzel maskeler takmay1 tercih ediyorum. & 2,32 & 1,45 \\
\hline 9 & Evde kendi maskemi kendim dikiyorum. & 1,86 & 1,21 \\
\hline 10 & $\begin{array}{l}\text { Kendi diktiğim ya da dışarıdan satın aldığım maskeleri güzel } \\
\text { görünsün diye süslüyorum. }\end{array}$ & $1,69^{*}$ & 1,15 \\
\hline 11 & Mevcut satışı yapılan maskeleri estetik bulmuyorum. & 2,53 & 0,36 \\
\hline 12 & Yer ve mekâna göre farklı maskeler kullanıyorum. & 1,77 & 1,26 \\
\hline 13 & $\begin{array}{l}\text { Kumaş maske kullanmayı, cerrahi maske kullanmaya tercih } \\
\text { ediyorum. }\end{array}$ & 2,21 & 0,46 \\
\hline 14 & Y1kanabilir maskeler kullanmayı tercih ediyorum. & 2,48 & 1,56 \\
\hline 15 & $\begin{array}{l}\text { Aldığım ya da diktiğim maskelerin kolay giyilip, çıkarılmasına } \\
\text { dikkat ediyorum. }\end{array}$ & 3,79 & 1,46 \\
\hline 16 & $\begin{array}{l}\text { Dışarıya çıarken sadece kendimin değil tüm aile bireylerinin } \\
\text { takmasını önemsiyorum. }\end{array}$ & $4,53^{*}$ & 1,06 \\
\hline 17 & $\begin{array}{l}\text { Maske satın alırken desenli, renkli, kıyafetime uygun kumaş } \\
\text { maske tercih ediyorum. }\end{array}$ & 1,91 & 1,37 \\
\hline 18 & $\begin{array}{l}\text { Maske satın alırken klasik beyaz renk tıbbi maske olmasına } \\
\text { dikkat ediyorum. }\end{array}$ & 3,44 & 1,51 \\
\hline 19 & $\begin{array}{l}\text { Zorunlu olmayan yerlerde de mutlaka maske takmayı tercih } \\
\text { ediyorum. }\end{array}$ & 3,80 & 1,38 \\
\hline 20 & $\begin{array}{l}\text { Tıbbi maskeyi tek kullanımlık olarak değil birkaç defa } \\
\text { kullandıktan sonra atıyorum. }\end{array}$ & 2,51 & 1,46 \\
\hline GENEL & & 2,90 & ,506 \\
\hline
\end{tabular}

Tablo 1, incelendiğinde, katılımcıların maske kullanımına ilişkin her maddeye verdikleri cevapların aritmetik ortalamalarına göre en yüksek ortalamaya "dışarıya çıkarken sadece kendimin değil tüm aile bireylerinin takmasını önemsiyorum" ile madde $16(\overline{\mathrm{X}}=4,53)$, en düşük ortalamaya ise "kendi diktiğim ya da dişarıdan satın aldığım maskeleri güzel görünsün diye süslüyorum" ile madde $10(\overline{\mathrm{X}}=1,69)$ sahiptir. Ayrica anket maddelerinin genel ortalamas $1(\overline{\mathrm{X}}=2,96)$ "Ara sira" yaparım düzeyindedir. Anket maddeleri arasında yer alan "T1bbı maskeyi tek kullanımlık olarak 
değil, birkaç defa kullandıktan sonra atıyorum" maddesinin düşük değerde $(\bar{X}=2,51)$ çıkmamasıda araştırmada ulaşılan bir diğer sonuçtur. Bu sonuca bağlı olarak, katılımcıların tıbbı maskenin kullanımına yönelik yanlış bir algı içerisinde oldukları söylenebilir.

Tüm dünya genelinde, salgının yaşandığı şu dönemde toplumun tüm bireylerinin, hem kendilerini korumak hem de çevrelerindeki diğer insanlara zarar vermemek adına maske takmaları oldukça önemli hale gelmiştir. Araştırmada maske kullanımına yönelik görüşler ile ikamet edilen yer değişkeni arasında anlamlı bir fark olup olmadığını ortaya çıkarmaya yönelik tek yönlü varyans analizi yapılmıştır. Analize ilişkin veriler Tablo 2'de yer almaktadır.

Tablo 2: Maske Kullanımına Yönelik Görüşler İle İkamet Edilen Yer Değişkenine İlişkin Varyans Analizi (ANOVA) Sonuçları

\begin{tabular}{|c|c|c|c|c|c|c|c|c|c|c|c|}
\hline İkamet yeri & $\mathrm{N}$ & $\overline{\mathrm{x}}$ & Ss & $\begin{array}{c}\text { Varyansın } \\
\text { kaynağ1 }\end{array}$ & KT & $\mathrm{df}$ & KO & $\mathrm{F}$ & $\mathrm{p}$ & Scheffe & $\eta^{2}$ \\
\hline $\begin{array}{l}\text { Sehir } \\
\text { merkezi } \\
\text { (A) }\end{array}$ & 251 & 2,81 & , 483 & \multirow{3}{*}{$\begin{array}{c}\text { G.Aras1 } \\
\text { G.İçi }\end{array}$} & \multirow{3}{*}{$\begin{array}{c}6,14 \\
89,89\end{array}$} & \multirow{3}{*}{$\begin{array}{c}2 \\
373\end{array}$} & \multirow{3}{*}{$\begin{array}{l}3,07 \\
\\
, 241\end{array}$} & \multirow{3}{*}{12,7} & \multirow{3}{*}{,000 } & \multirow{4}{*}{$\begin{array}{l}\text { B-A } \\
\text { B-C } \\
\text { A-C }\end{array}$} & \multirow{3}{*}{.064} \\
\hline $\begin{array}{l}\text { İlçe } \\
\text { (B) }\end{array}$ & 89 & 3,02 & ,509 & & & & & & & & \\
\hline $\begin{array}{c}\text { Kirsal } \\
\text { (C) }\end{array}$ & 36 & 2,18 & ,495 & & & & & & & & \\
\hline Toplam & 376 & 2,87 & ,506 & & 96,03 & 375 & & & & & \\
\hline
\end{tabular}

Tablo 2'ye göre, maske kullanımına göre görüşler ile ikamet edilen yer değişkeni arasında istatistiki olarak anlamlı bir farklılık vardır $\left(\mathrm{F}_{(2-373)}=12,7 ; \mathrm{p}<.05\right)$. Farkın kaynağını bulmak için yapılan, Scheffe testi analiz sonuçlarına göre, bu farkın ilçede ikamet edenler ile şehir merkezinde ve kırsalda ikamet edenler ve şehir merkezinde oturanlar ile kırsal bölgede ikamet edenler arasında olduğu görülmektedir. Tek yönlü varyans analizinde istatistiki anlamda ortaya çıkan farkın etki büyüklüğü eta-kare $\left(\eta^{2}\right)$ formülü ile hesaplanmaktadır. Green ve Salkind (2005), etki değerinin alabileceği değerlerin, 02-.05 arasında olursa küçük etki, 05-.08 arasında olursa orta büyüklükte bir etki, .08 ve üzeri olursa yüksek düzeyde bir etki olduğunu belirtmişlerdir. Bu ifadeden hareketle, test sonucu hesaplanan etki büyüklüğü bu farkın orta düzeyde $(\eta 2=.064)$ olduğunu göstermektedir.

Her ülke maske kullanımına yönelik halkını uyararak, maske takmanın güvenli ve düşünceli bir davranış olduğunu anlatmaya çalışmaktadır. Araştırmada maske kullanımına yönelik görüşler ile eğitim düzeyi değişkeni arasında anlamlı bir fark olup olmadığını ortaya çıkarmaya yönelik tek yönlü varyans analizi yapılmıştır. Analize ilişkin veriler Tablo 3'de yer almaktadır.

Tablo 3: Maske Kullanımına Yönelik Görüşler İle Eğitim Düzeyi Değişkenine İlişkin Varyans Analizi (ANOVA) Sonuçları

\begin{tabular}{|c|c|c|c|c|c|c|c|c|c|c|c|}
\hline Eğitim düzeyi & $\mathrm{N}$ & $\bar{X}$ & Ss & $\begin{array}{c}\text { Varyansın } \\
\text { kaynağ } 1\end{array}$ & KT & df & $\mathrm{KO}$ & $\mathrm{F}$ & $\mathrm{p}$ & Scheffe & $\eta^{2}$ \\
\hline İlkokul (A) & 15 & 2,81 & ,558 & \multirow{4}{*}{$\begin{array}{c}\text { G.Arası } \\
\text { G.İçi }\end{array}$} & \multirow{4}{*}{$\begin{array}{c}8,82 \\
87,20\end{array}$} & \multirow{4}{*}{$\begin{array}{c}3 \\
372\end{array}$} & \multirow{4}{*}{$\begin{array}{l}2,94 \\
, 234\end{array}$} & \multirow{4}{*}{12,5} & \multirow{4}{*}{, 000} & \multirow{4}{*}{$\begin{array}{l}\text { A-D } \\
\text { B-D } \\
\text { A-B }\end{array}$} & \multirow{4}{*}{.092} \\
\hline $\begin{array}{l}\text { Ortaokul } \\
\text { (B) }\end{array}$ & 22 & 3,09 & ,515 & & & & & & & & \\
\hline $\begin{array}{c}\text { Lise } \\
(\mathrm{C}) \\
\end{array}$ & 65 & 3,20 & ,503 & & & & & & & & \\
\hline $\begin{array}{l}\text { Yükseköğretim } \\
\text { (D) }\end{array}$ & 274 & 3,25 & ,473 & & & & & & & & \\
\hline Toplam & 376 & 3,08 & ,506 & & 96,03 & 375 & & & & & \\
\hline
\end{tabular}


Tablo 3'e göre, maske kullanımına göre görüşler ile eğitim düzeyi değişkeni arasında istatistiki olarak anlamlı bir farklılık vardır $\left(\mathrm{F}_{(3-372)}=12,5 ; \mathrm{p}<.05\right)$. Farkın kaynağını bulmak için yapılan, Scheffe testi analiz sonuçlarına göre bu farkın, yükseköğretim, ilkokul ve ortaokul mezunları ile ilkokul ve ortaokul mezunları arasında olduğu görülmektedir. Tek yönlü varyans analizinde istatistiki anlamda ortaya çıkan farkın etki büyüklüğü eta-kare $\left(\eta^{2}\right)$ formülü ile hesaplanmaktadır. Test sonucu hesaplanan etki büyüklügü bu farkın yüksek düzeyde $(\eta 2=.092)$ olduğunu göstermektedir.

Bazı ülkelerde maske takmak Covid-19 pandemisinden önce de normal olarak görülmekteydi. Bundan dolayı maske modası denilen bir kavram bile ortaya çıkmış, özellikle, Hong Kong'da bir dönem HelloKitty maskeleri çok popüler olmuştu. Araştırmada maske kullanımına yönelik görüşler ile çalışma durumu değişkeni arasında anlamlı bir fark olup olmadığını ortaya çıkarmaya yönelik t-testi yapılmıştır. Analize ilişkin veriler Tablo 4'de yer almaktadır.

Tablo 4: Maske Kullanımına Yönelik Görüşler İle Çalışma Durumu Değişkenine İlişkin t-testi Sonuçları

\begin{tabular}{lcccccc}
\hline Çalışma durumu & $\mathrm{n}$ & $\overline{\mathrm{X}}$ & $\mathrm{Ss}$ & $\mathrm{sd}$ & $\mathrm{t}$ & $\mathrm{p}$ \\
\hline Çalışıorum & 166 & 2,89 &, 531 & \multirow{2}{*}{374} & \multirow{2}{*}{,- 236} & \multirow{2}{*}{, 813} \\
\hline Çalışmıyorum & 210 & 2,90 &, 486 & & & \\
\cline { 1 - 3 }$* 0,05$ & & & & & &
\end{tabular}

Tablo 4'e göre, katılımcıların maske kullanımına yönelik görüşleri ile çalışma durumu değişkeni arasında anlamlı bir farklılık bulunmamaktadır $\left(\mathrm{t}_{(374)}=-, 236, \mathrm{p}>, 05\right)$.

Doğu Asya ülkelerinde Covid- 19 virüsü öncesinde özellikle sars virüsünün ortaya çıkması ile birlikte, kamusal alan içerisinde maske takmayı bireyler içsel bir zorunluluk olarak hissediyorlardı. Özellikle grip olan ya da alerjik bünyeli insanların kamuya açık alanlarda hapşırma ve öksürme davranışında bulunmaları kabalık olarak değerlendirilmekteydi. Araştırmada maske kullanımına yönelik görüşler ile yaş değişkeni arasında anlamlı bir fark olup olmadığını ortaya çıkarmaya yönelik tek yönlü varyans analizi yapılmıştır. Analize ilişkin veriler Tablo 5'de yer almaktadır.

Tablo 5: Maske Kullanımına Yönelik Görüşler İle Yaş Değişkenine İlişkin Varyans Analizi (ANOVA) Sonuçları

\begin{tabular}{|c|c|c|c|c|c|c|c|c|c|c|c|}
\hline Yaş & $\mathrm{N}$ & $\bar{X}$ & Ss & $\begin{array}{c}\text { Varyansınka } \\
\text { ynağı }\end{array}$ & KT & df & $\mathrm{KO}$ & $\mathrm{F}$ & $\mathrm{p}$ & Scheffe & $\eta^{2}$ \\
\hline $\begin{array}{c}20-30 \\
(\mathrm{~A})\end{array}$ & 196 & 2,84 & ,455 & \multirow{3}{*}{$\begin{array}{l}\text { G.Arası } \\
\text { G.İçi }\end{array}$} & \multirow{3}{*}{$\begin{array}{r}3,19 \\
92,83\end{array}$} & \multirow{3}{*}{$\begin{array}{c}3 \\
372\end{array}$} & \multirow{3}{*}{$\begin{array}{l}1,06 \\
, 250\end{array}$} & \multirow{3}{*}{4,27} & \multirow{3}{*}{,006 } & \multirow{3}{*}{$\begin{array}{l}\text { A-B } \\
\text { B-D }\end{array}$} & \multirow{5}{*}{.033} \\
\hline $\begin{array}{l}31-40 \\
\text { (B) }\end{array}$ & 89 & 3,25 & ,486 & & & & & & & & \\
\hline $\begin{array}{l}41-50 \\
(\mathrm{C})\end{array}$ & 74 & 2,97 & ,599 & & & & & & & & \\
\hline $\begin{array}{l}51-60 \\
(\mathrm{D})\end{array}$ & 17 & 2,91 &, 575 & & & & & & & & \\
\hline Toplam & 376 & 2,90 & ,506 & & 96,03 & 375 & & & & & \\
\hline
\end{tabular}

Tablo 5'e göre, maske kullanımına göre görüşler ile yaş değişkeni arasında istatistiki olarak anlamlı bir farklılık vardır $\left(\mathrm{F}_{(3-372)}=4,27 ; \mathrm{p}<.05\right)$. Farkın kaynağını bulmak için yapılan, Scheffe testi analiz sonuçlarına göre bu farkın, 20-30 yaş ile 31-40 yaş arası ve 31-40 yaş ile 51-60 yaş arasında olduğu görülmektedir. Tek yönlü varyans analizinde istatistiki anlamda ortaya çıkan 
farkın etki büyüklüğü eta-kare $\left(\eta^{2}\right)$ formülü ile hesaplanmaktadır. Test sonucu hesaplanan etki büyüklüğü bu farkın düşük düzeyde ( $\eta 2=.033)$ olduğunu göstermektedir.

\section{Sonuç, Tartışma ve Öneriler}

Türkiye'ninde içinde yer aldığ 1 ve 120 'den fazla ülkeye yayılan Covid-19 pandemisi halen insanlar için bir tehtid niteliğinde olmaya devam etmektedir (Ma, 2020; Balachandar vd., 2020). Dünya'da yürütülen önlemlerde olduğu gibi Türkiye'de de sağlık otoriterleri ve devlet yöneticileri tarafından salgınla mücadele kapsamında birçok önlemler alınmaktadır. Bu önlemler arasında maske kullanımı en üst sıralarda yer almaktadır. Bu çalışmada da maske kullanımı ile ilgili Gaziantep il merkezi, ilçe ve kırsal kesimlerinde yaşayan, farklı yaş ve eğitim düzeyine sahip kadın katılımcılara anket çalışması uygulanmıştır. Çalışma neticesinde aşağıda maddeler halinde verilen sonuçlar elde edilmiştir.

- Araştırmanın katılımcıları, salgın sürecinde sadece kendi sağlıklarını değil, yakın çevrelerini de salgından koruma inancına sahiptirler.

- Maske tercihleri incelendiğinde, ankete katılan kadın katılımcıların maske tercihinde süslü maske yerine, salgından koruma amaçlı takılması gereken cerrahi maskeyi öncelikledikleri saptanmıştır. Bu konuda yapılan akademik çalışmalar incelendiğinde de benzer sonuçlar elde edilmiştir (Bartozsko, Farooqi \& Alhazzani, 2020; Javid, 2020; Eikenberry, 2020).

- Ankete katılan katılımcıların büyük çoğunluğunun, devlet yöneticilerinin ve sağlık otoriterlerinin zorunlu kıldığı alanlar dışında bile maske takmayı tercih ettikleri sonucuna ulaşılmıştır.

- 20-30 yaş aralığında yer alan kişilerin 31 yaş ve üzeri kişilere nazaran hastalığ daha az önemsediği ve bundan dolayı maske kullanımını daha az tercih ettikleri sonucuna ulaşı1mıştır. Bu bulguya bağlı olarak, 20-30 yaş aralığında olan kişilerin, virüsün ilk ortaya çıktığı süreçte salğından daha çok 65 yaş ve üzeri kişilerin daha çok etkilediği kanısından hareketle, kendilerini virüs karşısında daha korunaklı gördükleri söylenebilir. Oysaki ABD yapılan araştırmalara göre, genç yetişkenlerde Covid-19 virüsüne karşı sanıldığı gibi dayanaklı değillerdir.

- Eğitim düzeyi yükseldikçe hastalığa karşı sağlık bilincinin artarak, maske kullanımının da arttığı saptanmıştır.

- Kırsal kesimde yaşayan kişilerin eğitim düzeyi ve yaş gruplarından bağımsız olarak maske kullanımını önemsemediği ortaya çıkmıştır. Bunun, kırsal kesimde yaşayan insanların daha sağlıklı ortamda yaşadıklarına olan inançlarından kaynaklı olabileceği söylenebilir.

- Kişilerin yer ve mekâna bağlı olarak farklı maske tercih etmediği, maskeyi evde kumaş parçalarından dikmek yerine koruyuculuğu yüksek cerrahi maske satın almayı tercih ettikleri bulgulanmıştır. Daha önceki çalışmalarda araştırmacılar da cerrahi maskelerin koruyuculuk oranlarının daha yüksek olduğu sonucuna varmışlardır (Leung vd., 2020; Greenhulg; 2020, Eikenberry, 2020; Szarpakvd, 2020).

- Anket sonucunda, bireylerin tek kullanımlık cerrahi maskeyi atmayıp tekrar tekrar kullandıkları ortaya çıkmıştır. Elde edilen bu sonuç literatür ile örtüşmememektedir (WHO, 2020). $\mathrm{Bu}$ bulguya göre katılımcıların maske kullanımına yönelik yanlış bir algı içerisinde oldukları yorumunda bulunulabilinir. Bu söylemi destekler nitelikte, Türk Toraks Derneği (2020), cerrahi maskeler ve solunum maskelerinin tek kullanım olduğunu yanlızca solunum maskelerinin, cerrahi maskelere göre çok daha pahalı olması nedeniyle tekrar kullanma eğiliminin olabileceğini belirtmiştir. 
- İstatistik sonuçlarına göre anket içinde yer alan madde 16 "Dışarıya çıkarken sadece kendimin değil tüm aile bireylerinin takmasını önemsiyorum" $(\overline{\mathrm{X}}=4,53)$ en yüksek aritmetik ortalamaya sahiptir. En düşük ortalamaya ise "Kendi diktiğim ya da dişarıdan satın aldığım maskeleri güzel görünsün diye süslüyorum." ile madde 10'un $(\overline{\mathrm{X}}=1,69)$ sahip olduğu sonucuna ulaşılmıştır. Ayrıca anket maddelerinin genel ortalaması $(\overline{\mathrm{X}}=2,96)$ "Ara sıra" yaparım düzeyindedir. $\mathrm{Bu}$ sonuca göre maske kullanımına yönelik oluşturulmaya çalışılan toplumsal bilincin hala tam olarak oluşmadığını söyleyebiliriz.

Özetle, katılımcıların maske kullanımını bir görsel kirlilik olarak görmedikleri, kendileri ve diğer aile bireylerini korumayı önemsedikleri için maske kullanmayı tercih eğilimlerinin yüksek olduğu, eğitim düzeyi, yaş ve ikamet edilen yer değişkenlerine göre maske kullamına yönelik görüşlerin farklılaştığı sonucuna ulaşılmıştır. Tarihin farklı dönemlerinde Dünya'da ortaya çıkan salgın hastalıkları insanoğlu yenmeyi başarmıştır. Günümüzde ortaya çıkan Covid-19 salgınını da gerek teknolojik imkânları kullanarak gerekse koruyucu ekipmanları kullanarak minimum seviyede atlatmanın mümkün olabileceğini söyleyebiliriz. Özellikle ileri düzey akıllı teknolojiler sayesinde, salgın hakkında kısa sürede bilgi edinilmiş ve maske takmak, el yıkamak ve sosyal izolasyon gibi basit yöntemlerle hastalığın yayılımını azaltmanın olası olduğu bulunmuştur. Sonuç olarak bu ve buna benzer salgınlarda kişisel koruyucu önlemlerin ne denli önemli olduğu ve bu koruyucu önlemlerin artık hayatımızın bir parçası haline gelmesi gerektiği kaçınılmaz hale gelmiştir. Çünkü bireylerin salgın ile ilgili risk faktörlerini küçümsemeden bilimsel veriler 1şığında gerekli tedbirleri uygulaması hem birey sağlığı, hem de toplum sağlığına olumlu yönde katkı sağlayacaktır. Bu çalışma Gaziantep ili ile sınırlıdır. İleri çalışmalarda farklı coğrafi bölgelerden ve daha büyük katılımcı kitlelerinden veriler toplanabilir. Ayrıca maske kullanmama nedenleri üzerine daha derinlemesine çalışmalar yapılabilinir.

\section{Kaynakça}

Acar, E. (2020). Covid-19: Modern devletin dirilişi mi yoksa krizi mi?. Birikim Dergisi.https://www.birikimdergisi.com/guncel/10081/covid-19-modern-devletin-dirilisimi-yoksa-krizi-mi

Akgül, Ö. (2020). Sars-CoV-2/Covid-19 pandemisi, Tıp Fakültesi Klinikleri, 3(1), 1-4. http://dx.doi.org/10.17932/IAU.TFK.2018.008/2020.301/tfk_v03i1001

Alpago, H., \& Oduncu Alpago, D. (2020). Koronavirüs salgınının sosyoekonomik sonuçları. IBAD Sosyal Bilimler Dergisi, 8, 99-104. http://dx.doi.org/10.21733/ibad.716444

Aslan, R. (2020). Tarihten günümüze epidemiler: pandemiler ve covid-19, Göller Bölgesi Ayllk Ekonomi ve Kültür Dergisi, 8(85), 35-39.http://dx.doi.org/

Balachandar, V., Mahalaxmi, I., Kaavya J., Vivekanandhan, G., Ajithkumar, S., Arul, N., Singaravelu, G., Senthil Kumar, N., \& Mohana Devi, S., (2020). European Review for Medical and Pharmacological Sciences, 24, 3422-3425, http://dx.doi.org/10.26355/eurrev_202003_20713

Bartoszko, J.,Farooqi, M.A.M., \& Alhazzani, W. (2020). Medical Masksvs N95 respirators for Preventing Covid-19 in Healthcare Workers: A systematic Riviewand Meta-Analysis of Randomized Trials, Influenza and Other Respiratory Viruses, 00, 1-9, http://dx.doi.org/10.1111/irv.12745.

Büyüköztürk, Ş., Kılıç Çakmak, E., Akgün, Ö.E., Karadeniz, Ş., \& Demirel, F. (2014). Bilimsel araştırma yöntemleri. Ankara: Pegem Akademi. 
Doğan, H. (2017). Vefayata mahsus vukuat ve toplum. Ĕgitim Bilimleri ve Sosyal Araştırmalar Dergisi, 6(18), 597-616. http://dx.doi.org/

Eikenberry, S.E.,Mancuso, M., Iboi, E., Phan, T., Eikenberry, K., Kuang, Y. Kostelich, E., \& Gumel, A.B. (2020), To mask or Not To Mask: Modelling the Potential for Face Mask Use by the General Publicto Curtail the Covid-19 Pandemic, Infectious Disease Modelling, 5, 293-308, http://dx.doi.org/10.1016/j.idm.2020.01.001

Fraenkel, J.R., \& Wallen, N.E. (2006). How todesignandevaluateresearch in education. NY: McGraw-Hill.

Green, S.B., \& Salkind, N.J. (2005). Using SPSS for windows and macintosh: Analysing and understanding data (Fourth Edition). Upper Saddle River, NJ: Prentice Hall.

Greenhalgh, T., Schmid, M., Czpionka, T., Bassler, D., \& Gruer, L., (2020). Face Masks for the

Public During the Covid-19 Crisis, BMJ Analysis, 369, 1-14, http://dx.doi.org/10.1136/bmj.m1435

Gönüllü, A.R. (2008). Antalya'da salgın hastalıklar (1894-1922), Atatürk Araştırma Merkezi Derneği Dergisi, 24(71), 445-484.

Javid, B.,Weekes, M., \& Matheson, N. (2020), Covid-19: ShouldthePublicWearFaceMasks?, BMJ, 369,1-2, http://dx.doi.org/10.1136/bmj.m1442

Kaya, Ş., \& Kıyıl1, R. (2014). Antakya'da Ortaçağ'da meydana gelen doğal âfet ve salgın hastalıklara bir bakış/contagious diseases and natural disasters that occured in antioch in the Medieval Ages, Mustafa Kemal Üniversitesi Sosyal Bilimler Enstitüsü Dergisi, 6 (12), 403-418.

Kına, H.,Özkan,S., İlhan, M.N., \& Dikmen, U. (2020). COVID-19 epidemiyolojisi: pandemiden ne öğrendik,,Journal of Biotechnologyand Strategic HealthResearch, 4, 2936http://dx.doi.org/10.34084/bshr.715153

Lu, H., Stratton, C.W., \& Tang, YW. Outbreak of neumonia of unknown etiology in Wuhan, China: The mystery and the miracle. J Med Virol., 92(4): 401-2

Ma, Q.,Shan, Hu., Zhang, H., Li, G., Yang, R., \& Chen, J., (2020), Potential Utilities of Mask Wearing and Instant and Hygiene for fighting SARS-CoV-2. Journal of Medical Virology, 1-5, http://dx.doi.org/10.1002/jmv.25805

Morga, G. A.,Leech, N. L., Gloeckner, G.N., \& Barrett, K.C. (2004). SPSS for introductory statistics-use and interpretation. London: Lawrence Erlbaum Associates.

Özdemir Deniz, P.,\& Evci Kiraz, E.D. (2020). Covid-19 pandemi sürecinde şehir sağlı̆g çalışmaları, Deneysel, Biyoteknolojik, Klinik ve Stratejik, Sağlık Araştırmaları Derneği Dergisi, 1, 147-151. http://dx.doi.org/10.34084/bshr.726231

Özkan, S., Tüzün, H., Dikmen, A.U., \& İlhan, M.N. (2020). Salgınlarda toplum davranışı ve sağlık okuryazarlığ1, Journal of Biotechnology and Strategic Health Research, 1, 105-110. http://dx.doi.org/10.34084/bshr.719139

Seçkin, Ç., \& Özçiftçi, S. (2020). COVID-19 pandemisinin sosyal yaşam ve etik düzlem üzerine etkileri: bir değerlendirme çalışması. Anadolu Kliniği Tup Bilimleri Dergisi, 25(1), 142153.

Soysal, F., İşler, S.C., Peker, İ., Akca, G., Özmeriç, N., \& Ünsal, B. (2020). COVID-19 pandemisinin diş hekimliği uygulamalarına etkisi, Klimik Derg., 33(1), 5-14. 
Szarpak, L., Smereka, J., Filipiak, K.J., Ladny, J.R., \& Jaguszewski, M., (2020). Cloth Masks Versus Medical Masks for COVID-19 Protection, Cardiology Journal, 27(2), 218-219 http://dx.doi.org/10.5603/CJ.a2020.0054

Şimşek, K. (2020). Osmanlı Dönemi'nde Denizli'de salgın hastalıklar, Pamukkale Üniversitesi Sosyal Bilimler Enstitüsü Dergisi, 38, 163-176. http://dx.doi.org/10.30794/pausbed.644266

Türk Toraks Derneği (2020). Maske çeşitleri ve kullanım özellikleri. https://www.toraks.org.tr/halk/News.aspx?detail=5831

Yalçın, S. (2020). Diş hekimliğinde yeni dönem covid-19 pandemisi ve alınacak önlemler. Quintessence Publishing.

Yücel, G. (2019). Malatya'da kolera salgını ve devletin müdahale çabaları (1892-1894)Choleraepidemics in Malatya andstatenterventionefforts (1892-1894), Inönü Üniversitesi Sağllk Hizmetleri Meslek Yüksek Okulu Dergisi, 7(1), 108-121. http://dx.doi.org/10.33715/inonusaglik.560022

WHO, (2020). Advice on theuse of masks in the community, during home care, and in health care settings in the context of COVID-19, WHO/2019-nCoV/IPC_Masks/2020.2. 